\title{
The Beat "Pad"
}

Heike Mlakar

Hildesheim University

Follow this and additional works at: https://docs.lib.purdue.edu/clcweb

Part of the American Literature Commons

Dedicated to the dissemination of scholarly and professional information, Purdue University Press selects, develops, and distributes quality resources in several key subject areas for which its parent university is famous, including business, technology, health, veterinary medicine, and other selected disciplines in the humanities and sciences.

CLCWeb: Comparative Literature and Culture, the peer-reviewed, full-text, and open-access learned journal in the humanities and social sciences, publishes new scholarship following tenets of the discipline of comparative literature and the field of cultural studies designated as "comparative cultural studies." Publications in the journal are indexed in the Annual Bibliography of English Language and Literature (Chadwyck-Healey), the Arts and Humanities Citation Index (Thomson Reuters ISI), the Humanities Index (Wilson), Humanities International Complete (EBSCO), the International Bibliography of the Modern Language Association of America, and Scopus (Elsevier). The journal is affiliated with the Purdue University Press monograph series of Books in Comparative Cultural Studies. Contact: <clcweb@purdue.edu>

\section{Recommended Citation}

Mlakar, Heike. "The Beat "Pad"." CLCWeb: Comparative Literature and Culture 18.5 (2016): <https://doi.org/10.7771/ 1481-4374.2928>

This text has been double-blind peer reviewed by $2+1$ experts in the field.

The above text, published by Purdue University Press @Purdue University, has been downloaded 130 times as of $11 /$ $07 / 19$.

This document has been made available through Purdue e-Pubs, a service of the Purdue University Libraries. Please contact epubs@purdue.edu for additional information.

This is an Open Access journal. This means that it uses a funding model that does not charge readers or their institutions for access. Readers may freely read, download, copy, distribute, print, search, or link to the full texts of articles. This journal is covered under the CC BY-NC-ND license. 


\section{PURDUE}

UNIVERSITY PRESS <http://www.thepress.purdue.edu>

\section{CLCWeb: Comparative Literature and Culture}

ISSN 1481-4374 <http://docs.lib.purdue.edu/clcweb> Purdue University Press @Purdue University

CLCWeb: Comparative Literature and Culture, the peer-reviewed, full-text, and open-access learned journal in the humanities and social sciences, publishes new scholarship following tenets of the discipline of comparative literature and the field of cultural studies designated as "comparative cultural studies." In addition to the publication of articles, the journal publishes review articles of scholarly books and publishes research material in its Library Series. Publications in the journal are indexed in the Annual Bibliography of English Language and Literature (Chadwyck-Healey), the Arts and Humanities Citation Index (Thomson Reuters ISI), the Humanities Index (Wilson), Humanities International Complete (EBSCO), the International Bibliography of the Modern Language Association of America, and Scopus (Elsevier). The journal is affiliated with the Purdue University Press monograph series of Books in Comparative Cultural Studies. Contact: <clcweb@purdue.edu>

\section{Volume 18 Issue 5 (December 2016) Article 15 \\ Heike Mlakar, \\ "The Beat 'Pad'" \\ <http://docs.lib.purdue.edu/clcweb/vol18/iss5/15>}

Contents of CLCWeb: Comparative Literature and Culture 18.5 (2016)

Special Issue Beat Studies Go Global. Ed. Oliver Harris and Polina Mackay

<http://docs.lib.purdue.edu/clcweb/vol18/iss5/>

Abstract: In her article "The Beat 'Pad'" Heike Mlakar analyzes the importance of Joan Vollmer's and Hettie Jones's Manhattan apartments as centers for the upcoming avant-garde movement of the time in order to understand the meaning of "home" in postwar bohemianism in general and specifically for female Beats. In sensationalized late 1950s films and in print media, the Beats were associated with low-rent Beat "pads" in poor urban areas, in which wild all-night parties were held-sites of drug use, destitution, and sexual promiscuity. Both Vollmer and Jones contributed greatly to the formation of the Beat Generation by providing the perfect setting for the flourishing of the artistic scene that would change the postwar literary scene forever: it was here, in Vollmer's Apartment 51, that the cornerstone for a new era in literature was laid, as Ginsberg, Burroughs, and Kerouac lived there simultaneously from 1945 to 1946. Similarly, the "pads" Hettie Jones shared with then-husband Amiri Baraka served a similar function, namely to build up a homogeneous Beat identity. 


\section{Heike MLAKAR}

\section{The Beat "Pad"}

Beat chick dressed in black; bearded Beat wearing sandals, chinos, turtle-necked sweater and studying a record by the late saxophonist Charlie Parker; Italian wine bottle; marijuana for smoking; typewriter with half-finished poem; bare mattress: In Life Magazine's 30 November 1959 issue, journalist Paul O'Neil contributed an article called "The Only Rebellion Around" with an accompanying black and white staged photograph of a Beat couple with their baby "who has gone to sleep on floor after playing with beer cans" (115). They are in their Beat "pad" filled with stereotypical props. When analyzing the term Beat "pad," which turned up in film and print media in the late 1950s, one needs to consider the importance of salon women who paved the way to create intellectual environments. Although the Beat pad and the more noble French writers' salon served similar functions through fostering artistic bohemian subcultures, the former was shabby, run-down, and less fashionable than its Parisian counterpart. Prominent examples for literary salons include Madame de Rambouillet (1599-1665), Madame Geoffrin (1699-1777), Madame de Staël (1766-1817), and also Gertrude Stein, who hosted expatriate avant-garde artists and writers from all over Europe and the U.S. In the 1920s, Stein's salon at 27 Rue de Fleurus in Paris, with walls covered by avant-garde paintings of contemporary artists, attracted many of the great artists and writers, including Ernest Hemingway, Thornton Wilder, Sherwood Anderson, Pablo Picasso, Henri Matisse, and Georges Braque.

For the early Beat generation, salons were replaced by pads located in the center of Manhattan. They often served as bohemian meeting places which were immensely important for the flourishing of Beat literature. Beside Allen Ginsberg's Manhattan apartments at 170 East 2 ${ }^{\text {nd }}$ Street (1958-1961)where he wrote "Kaddish"-704 East 5th Street (1964-1965), and 408 East 10th Street (1965-1975), the spacious pads of Joan Vollmer and Hettie and LeRoi Jones are particularly noteworthy: Poetry and prose were read aloud to the others, writers and new publications were being discussed in great detail, and the wittiest reviewers were always directly and personally available. Within an instant, serious feedback on their writings could be received. Joan Vollmer and Edie Parker's 421 West $118^{\text {th }}$ Street and 420 West $115^{\text {th }}$ Street apartments were only a stone's throw away from the Columbia University campus and provided open room for the exchange of new ideas and attitudes. Vollmer would later become the common-law wife of William S. Burroughs while Parker married Jack Kerouac in August 1944, also so that she could post his bail after he had been jailed following the murder of David Kammerer. As Joyce Johnson put it: "In 1944 and '45, her [Vollmer's] apartment on 115th Street was an early prototype of what a later generation called pad-a psychic way station between the Village and Times Square, or between Morningside Heights and Lower Depths, in the mental geography of those who came together there, lived there sporadically, made love, wrote, suffered, experimented with drugs, in those six big rooms where Joan had lived alone with a newborn baby until Edie introduced her to Jack" (Minor 3). From September 1944 until 1948, Apartment 51 on 115th Street soon became an uptown outpost for an elite group of Beat writers, prostitutes, drug addicts, and petty criminals. Most of them had grown up in upper-middle to upper-class environments, with parents being wealthy bankers, judges, or entrepreneurs. Under her married name Mrs. Paul Adams, Vollmer had signed the lease for \$150 a month, moving in with Jack Kerouac and Edie Parker, whom she had met in the West End Bar. Vollmer herself had revolted against the boredom of her upper-class bourgeois upbringing in Loudonville, New York, just outside of Albany, where her father was the manager of the Gevaert photographic film factory. At 19, she had already escaped into marriage twice: As a Barnard student, she got married aged 17, but divorced soon after. Her second husband, Paul Adams, was a law student who was drafted into the army when the Second World War broke out. In the meantime, she was made pregnant by a Columbia student, and decided to carry the baby to term. Being married to Adams and getting money from both him and her father, however, gave Vollmer the freedom to live on her own, and she was far more radical about leading an independent bohemian life than her female friends (Miles, Call Me 120).

Vollmer's old-fashioned, high-ceilinged, six-bedroom apartment became the center and unofficial hangout for the early formation of Beat writers. Whenever Kerouac was not shipping out with the merchant marine, he was sharing a room with Parker, but their marriage was highly strained. Lucien Carr, then studying at Columbia, and his girlfriend Celine Young were frequent visitors, bringing with them a Columbia hall-mate named Allen Ginsberg. Carr also introduced the group to a friend from St. Louis named William Burroughs, the heir to the Burroughs adding-machine fortune. With $\$ 200$ a month from his parents, Burroughs enjoyed exploring the Times Square area. In spring 1945, Burroughs, who had been a steady guest for some time, finally moved into the best room of Vollmer's rambling 
apartment, with bookshelves and a large study desk-a room she had reserved just for him (Johnson, The Voice 192). Although predominately homosexual, Burroughs was fascinated with Vollmer's intellect, wit, intuition, and unusual insight. He regarded her as the smartest member of the group and the only one capable of inspiring him to take up new pursuits. Burroughs's brilliant mind, his proclamations about literature and society, and his sinister air attracted Vollmer.

In March 1945, Ginsberg had been suspended from classes at Columbia for a year after scrawling "Fuck the Jews!" and "Butler has no balls!"-Butler was Columbia's president-on the window pane (Johnson, The Voice 188) and consequently moved into one of Vollmer's empty bedrooms. In February of the same year, Ginsberg had already been threatened with eviction when a dean found Kerouac in his room one early morning. Haldon Chase, a Columbia anthropology student from Denver moved into Ginsberg's room in May 1945. In the months to come, they would hear a lot by Hal about a fabulous, self-educated friend from Denver, Neal Cassady-a notorious car thief who was reading his way through the Denver public library. When his letters from Colorado arrived, Chase would pass them around in the apartment. As Ginsberg recalled: "It was warm, very friendly, very family" (Schumacher 52). The roommates shared their money for home-cooked communal meals; they slept together, both chastely and having sex; they conducted "Dostoyevskian confrontations" and engaged in psychoanalysis. They all found the open exchange of ideas inspiring. Ginsberg remembered spending hours in Vollmer's room, having deep conversations, "with Bill lying on the bed, propped up with pillows, and Joan at his side with her arm around him" (Miles, Call Me 115).

The residents of Apartment 51 tried to be as frank and honest as possible with each other and various issues were out on the table: sitting on Vollmer's big bed in the living room, nothing should be left unmentioned and everything was open for discussion. Ginsberg recalled his friends talking of "their faggishness, or their campiness, or their neurasthenia, or their solitude, or their goofiness, or even ... their masculinity" (Johnson, The Voice 194)-reflections dismissed by the official literary discourse of the time. While Chase's unshakeable heterosexuality disappointed Ginsberg, it strengthened Kerouac's unsettled self-esteem. In her 2013 biography of Kerouac, Joyce Johnson sees Vollmer's $115^{\text {th }}$ Street pad as "something like a commune but most of all like a new kind of family of brothers and sisters. If there were erotic currents and entanglements among the various siblings-between Burroughs and Allen, between Allen and Jack, between Jack and Joan, even, briefly, between Herbert Huncke and Edie-they were played out very openly with no effort made to conceal them" (194). During the late 1940 s and 1950s, Burroughs, Ginsberg, Kerouac, and later Cassady were exploring tangled and shifting homosocialities. Despite the fact that Burroughs and Ginsberg were ostensibly homosexual and Cassady and Kerouac ostensibly heterosexual, the complexity and intensity of their bonds attests to the difficulty of separation "homosexual" from "homosocial" as the line between erotic liaisons and "just male friendship" blurs. In Apartment 51, money, however, became a constant tension between Kerouac and Parker, who was the only one in the household with a regular working income, being a cigarette girl at a Times Square nightclub six nights a week form $7 \mathrm{pm}$ to 4 am. At the beginning of July 1945, she escaped to a more stable life with her grandmother in Asbury Park. Kerouac, however, remained a fixture in Vollmer's apartment, even though now, with nobody paying his rent, he officially lived with his parents in Ozone Park.

By late fall 1945, the roommates' physical and mental states deteriorated. Burroughs had introduced the residents of Apartment 51 to a group of hustlers and drug dealers, like Huncke and Times Square prostitute Vicki Russell, who came from a rich Detroit family and who brought with them various kinds of drugs, like morphine and Benzedrine. The cheapest way to get high was to "buy over-thecounter Smith, Kline, and French inhalers, meant to last six months, crack the inhaler, remove the three-quarter-inch Benzedrine-soaked accordion strip of paper, and drop it in a cup of coffee or simply swallow it whole" (Watson 61-62). It was then that Burroughs started his lifelong addiction to heroin, and he was now selling narcotics in a cold-water flat on Henry Street. Huncke was an on-off visitor trafficking with drugs and bringing in some of his underworld connections, and Kerouac, Ginsberg, and Vollmer used Benzedrine and amphetamines excessively. All of them had wanted experiences they could write about, but now, with Kerouac losing his hair and having grey skin due to Benzedrine, everything fell apart. His Benzedrine experiences in Vollmer's pad climaxed in December 1945, with a five-day-and-night trip through New York with Ginsberg and Chase. Kerouac collapsed and was taken to Queens VA Hospital, where thrombophlebitis was diagnosed (Johnson, The Voice 207-8). Vollmer's Beat pad had turned from a literary salon into a drug den. While Ginsberg used his experimentation with drugs to explore his consciousness, Kerouac would describe 1946 as a year of "evil decadence" in Vanity of Duluoz (Maher 130). By the end of the summer of 1946, the "libertine circle," as Ginsberg called their group in his journals (Morgan 115), had almost dissolved. Hal Chase was gone as he "didn't see petty thievery and drug addiction as a valid form of rebellion in postwar America" (Morgan 
134), Burroughs was in Mexico after having been arrested for forging a narcotics prescription, Ginsberg served in the merchant marines, Parker lived with her grandmother, and Kerouac with his parents. With no roommates left, Herbert Huncke helped pay the rent by breaking into cars, feeling like Vollmer's protector while Burroughs was away. Vollmer's use of Benzedrine brought both grave physical and mental problems: she developed sores all over her body and became schizophrenic and paranoid. After her admission to Bellevue Hospital, Burroughs immediately returned to New York City to gain her release.

Together with his 15-year-old wife, LuAnne Henderson, Neal Cassady arrived at the 115 th Street apartment in December 1946. Walt Whitman wrote that before he produced Leaves of Grass (1855) he had been "simmering, simmering, simmering" until the influence of Ralph Waldo Emerson brought him to boil. Cassady, too, had that catalyzing effect on the literature of Kerouac and Ginsberg and added a vital element to the New York group of Beat writers. Poet Gary Snyder describes the impressions Neal Cassady left behind: "My vision of Cassady is of the 1890s cowboys, the type of person who works the high plains of the 1880 s and 1890s ... He is the Denver grandchild of the 1880 s cowboys with no range left to work on. Cassady's type is that frontier type, reduced to pool halls and driving back and forth across the country. Cassady was the energy of the archetypical west, the energy of the frontier, still coming down. Cassady is the cowboy crashing" (Charters, Kerouac 286). It was here, in Apartment 51, that this fateful encounter would change the postwar literary scene forever. In January 1947, Burroughs and Vollmer returned to St. Louis, Missouri, to visit Burroughs's parents, before moving to New Waverly, Texas, where they lived on a farm with Vollmer's daughter Julie in order to escape legal problems. Their son William Junior was born in July 1947. Future plans to make money by growing marijuana were not successful, as the couple mostly entertained guests, including their old friend Herbert Huncke. After another stopover in New Orleans, they moved to Mexico City in order to be safe from U.S. authorities. It was on 6 September 1951 that Burroughs accidentally killed Vollmer during a drunken attempt at playing William Tell in Mexico City and was consequently convicted of manslaughter. Not only Joan Vollmer provided the emerging Beat counterculture with an open door and open ear, but Hettie Jones (born 1934 as Hettie Cohen) also contributed her efforts to a larger whole. Hettie Jones's apartments at 7 Morton Street, 402 West 20th Street, 324 East 14th Street, and 27 Cooper Square were popular venues for artists of all kinds. She shared them with then-husband African American poet LeRoi Jones, who later changed his name to Amiri Baraka. Both the Joneses' founding of the magazine Yugen: A New Consciousness in Arts and Letters (1958-1962) and the establishment of an informal salon in their poorly equipped apartments were crucial factors to build up a homogeneous Beat identity. Besides Yugen, Hettie Jones and LeRoi Jones founded Totem Press and Corinth Books (1959-1969). Authors who were published were Gary Snider, Frank O'Hara, Joel Oppenheimer, Edward Dorn, and LeRoi Jones himself.

Hettie Jones's 1990 memoir How I became Hettie Jones depicts seven years (1957-1964) of a life in and around poetry. Born into a middle-class Jewish family in Queens, she is passing through poetry while remaining "in it," but at the same time writing little of it. On the one hand, the memoir details the jazz and literary scene of the Village and the Lower East Side as the bohemian 1950s evolved into the countercultural 1960s. On the other hand, the dividing line between private and public experience is central. Jones's struggle for independence, experiences with reproductive rights, the loss of her Jewish heritage, her revolutionary interracial marriage with LeRoi Jones as well as the book's overarching question, "Who is Hettie Jones?" point to the significant problematic of identity. In her memoir, the marking off of spaces-apartments, streets, and bars-triggers Jones's memory and facilitates the creation of her conflicted self. Jones's self can heal the wounds caused by her surrounding's racism and her husband's infidelity: in 1966, the Joneses got divorced as LeRoi became Amiri Baraka, prophet of the black arts movement, who could no longer live with a white woman in his pursuit of racial purity. Baraka, as a black intellectual, became increasingly estranged from whiteness: "It became clear that I could only really 'love' a white woman at the expanse of giving up the things in myself that I cared most about, the collective memory of Black love" (Watts 146). Fearing that he had imbibed the Euro-American world-view too much, a terrible sense of estrangement pulled him away from his wife, "until she became only, 'the white woman I am living with'" (146). Jones was left a single mother with two mixed-race children, the later writer Lisa Jones and the art historian Kellie Jones.

Jones uses the notion of "home" to structure her memoir, but skillfully deconstructs the term to escape the cliché of being a typical 1950s mother and housewife. In How I became Hettie Jones, places exist as temporal realities. Her pads play such a crucial role that they are even name-giving for the titles of the various chapters in her memoir: Morton Street, Twentieth Street, Fourteenth Street and Cooper Square-the place where she is still living today. 7 Morton Street, \#20, was Jones's first "room of her own." On New Year's Eve 1957, she moved in with a mattress, a gooseneck lamp, a phono- 
graph, and pots she never used. Some days later, her parents gave her the kitchen table they were throwing away. Most often when she was at home, she sat in front of the fireplace, burning vegetable crates from the Bleecker Street markets, eating Wheat Chex, and worrying about her future. What was to become of her? "I had just read William Carlos Williams, concluding that my own poems were not only bad but worthless. I missed the small, easy challenge of CMC's 'promotional literature.' Because what - or who - was the subject of Morton Street? My single-minded coming of age lacked conflict, I thought. If, as Aristotle claimed, the plot was the soul of the action, what was mine? What could be said of me? That I'd managed to get where I was? And where was that? Dick suggested I keep a journal. I wrote small impressions, likes and dislikes, about wanting to live unencumbered by things. I made a list of the men I'd slept with, to see if I could shock myself (I couldn't)" (Jones, Hettie Jones 24-25). In 1957, while working on staff for a small jazz periodical, The Record Changer, then Hettie Cohen met LeRoi Jones. Even in the Village, interracial relationships proved controversial at the time, and her Jewish family was shocked and turned their back on her. In 1958, LeRoi Jones initiated the idea to found a magazine which would publish the work of young writers. Inspired by "Howl," he wrote a letter to Allen Ginsberg on toilet paper, asking him if he would contribute some of his works for the new magazine. Ginsberg enriched the magazine by drawing from his broad network of friends: Soon, the Joneses' close circle of friends included Frank O'Hara, Jack Kerouac, Gregory Corso, William Burroughs, Gary Snider, Philip Whalen, and Joel Oppenheimer. For some time, Hettie Jones and Diane di Prima maintained a close friendship, however, LeRoi's affair with di Prima and their subsequent child strained that friendship. In March 1958, the first issue of Yugen appeared, and it would become the most influential magazine of the Beat era. "We rented a rickety IBM with erratic adjustable spacing, and rigged up a light box for pasteups; Roi collected poems and drawings - among the contributors Allen Ginsberg himself and the artist Tomi Ungerer; Dick Hadlock offered production advice; even the motor-scooter man from Ferry Street helped with graphics. Piece by piece I put it all together, on my old kitchen table, with a triangle and T-square borrowed from the Changer. Finally, 7 Morton Street, \#20, was semiprofessional!" (Jones, Hettie Jones 54). In extensive sessions, Hettie Jones carefully typed the poems and did the magazine's layout. Both the magazine and the Joneses' apartment gradually became a meeting point for the Beats' New York group. In eight issues, which appeared irregularly until December 1962, Yugen published not only Beats, but the San Francisco poets, the New York poets, and the Black Mountain poets. The opening poem of Yugen 1 was Philip Whalen's "Further Notice."

The Joneses' party guests included the regulars of the Cedar Bar, avant-garde painters, jazz musicians, and writers. Ginsberg described the atmosphere as "an acme of good feeling. A lot of mixing, black white hip classic" (Miles, Ginsberg 252). Before editing, publishing, and distributing Yugen, Hettie Jones had held various clerical jobs at one of the most prestigious literary journals of the twentieth century, the Partisan Review, and was friends with its editors Philip Rahv and William Phillips. After Partisan Review's spring 1958 issue which included Norman Podhoretz's attack on the Beat writers whom he called "The Know-Nothing Bohemians" (Charters, Brother 268), Jones successfully attempted to persuade Rahv and Phillips to publish an issue where the Beats had their own say. This subsequent issue featured writings by LeRoi Jones, Frank O'Hara, Denise Levertov or James Merrill. Due to Hettie Jones's contacts with Partisan Review and its distributer for small literary magazines, Bernard DeBoer, Yugen could be distributed beyond local newsstands and cafés out to the West Coast. This was an important step to establish credibility for the Beat movement and to make Beat literature accessible to a wider audience. Hettie Jones also made use of other personal contacts: Ted Wilentz, owner of The Eighth Street Bookshop, backed her by donating \$500 to typeset the magazine (Grace, Breaking 16465 ). Jones herself had not yet found a literary voice of her own, but the emerging scene led to a new knowledge of the world: "If I hadn't yet managed to speak for myself, here at least were these others" (Jones, Hettie Jones 55).

After moving out of Morton Street, the Joneses' next pad was on 402 West 20th Street. It was just off Ninth Avenue, where a lot of New York's art scene was taking place, and they had "nothing but party space to offer" (70). According to Hettie Jones, "Twentieth Street was a young time, a wild, wide open, hot time, full of love and rage and heart and soul and jism" (71). After poetry readings, they would bring home artists and writers like Kerouac and Ginsberg to their once elegant six-room parlor facing the Episcopal Seminary. On their couch and folding bed, they soon had "one or two weekly boarders, twenty or more weekend regulars, occasional bashes for hundreds. Under these circumstances, being the one who understands can get you a rep for sufferance. The writer Hubert (Cubby) Selby, Jr., once said, to my surprise, 'I always meant to apologize for those years we crashed all over you'" (71). Both Jones's memoir and LeRoi Jones's autobiography give insight into the Village years, with the Joneses' household as one of the centers for the avant-garde movement. In a 1988 interview, 
Ginsberg recalled the exhilarating creative and artistic energy of the time: "I met Langston Hughes at LeRoi Jones's party one night when Ornette Coleman was playing music and everyone was dancing. That's the only time I met Langston Hughes. In '59 or '60. A great touching moment in history. When Black Mountain, Beatniks, the Abstract Expressionists, the freedom jazz, the Harlem Renaissance, all met in one room" (Gennari 254). Rents in the Village were cheap, and cafés, bars, and galleries flowered. Before being able to afford the outhousing of the printing process to a professional company, Jones put together Yugen 3-6 and some smaller books "on a drafting board propped on the kitchen table" on 20th Street. Yugen was now also attracting attention in the literary scene and critic Gilbert Seldes commented that "though he wasn't always 'with' the poetry in Yugen he found in it a lot of feeling-his italics" (Jones, Hettie Jones 75). Hettie Jones explains where this particular feeling came from: "It was this that all my late-night cutting, pasting, aligning, and retyping finally taught me what comes from reading things over and over, taking apart and putting together, the heart of the matter, the way it feels" (75).

In 1959, Hettie and LeRoi Jones founded Totem Press, which intended to publish small books, mostly poetry, by different new writers. The Joneses' publishing of poetry and books continued when they lost their lease and moved into 324 East 14th Street in October 1960: "Manhattan has many real and imagined boundaries, but Fourteenth Street in 1960 seemed one of the clearest: a straight road the width of the island, east to west between uptown and down" (Jones, Hettie Jones 119). Many twentieth-century artists lived in the street. In the East Village's interracial avant-garde, LeRoi Jones "felt free to move and think as I wanted to, but I was nevertheless constantly running into the northern liberal bohemian varieties of racism and national oppression and tried to deal with it as I could" (Baraka 6). During the early 1960s, Jones became more radical in terms of race, and his poetry more politically intense. His visit to Cuba in July 1960 had dramatically changed his writing and goals, causing him to support black nationalist ideas and the Black Arts Movement. At 14th Street, the Joneses rented a parlor floor above a vacant store with dusty, discarded shoeboxes in the windows. According to LeRoi Jones, it was a "terrible though huge barn-like apartment" in a brick building-a block he depicts as "the grimy East Side just before the still vague 'East Village' changed abruptly into Chelsea East" (Maurer <http://bedfordandbowery.com/2014/01/when-amiri-baraka-was-leroi-jones-king-of-th e-lower-east-side/>). Life was not easy for them, because the pad was mostly unheated and ice cold. Jones writes, "I called Fourteenth Street the Court: hard to live in but great for games" (Hettie Jones 121). Leading a life in poverty, and as Jones writes in her memoir, it was hard to manage the fifty dollars for the rent. For some time, until they got a water heater, Hettie sat in the deep side of the double kitchen sink to bathe, with her feet in the shallow side and water poured from pails on the stove. After the apartment's kitchen ceiling fell down, the couple stopped paying the rent and were evicted.

27 Cooper Square is the last "home" described in How I became Hettie Jones. The Joneses illegally converted the top floor of a former rooming house that LeRoi Jones described as "a small group of rooms, the strangest-looking little apartment I'd ever seen, down on Cooper Square, a few steps from The Five Spot" (Maurer <http://bedfordandbowery.com/2014/01/when-amiri-baraka-was-leroi-jonesking-of-the-lower-east-side/>). The Five Spot was a jazz club located at 5 Cooper Square, famous also for the Ornette Coleman Quartet's historic 10-week engagement in 1959/60, which brought the avant-garde to jazz. 27 Cooper Square has been home of many writers, musicians, and painters, including jazz saxophonist Archie Shepp, painter Elizabeth Murray, jazz bassist and composer Norris Jones-better known as Sirone, and others. As Lorenzo Thomas points out, Manhattan's Lower East Side was a gloomy, run-down slum district with around 500.000 people living in crowded mass accommodation at the end of the nineteenth century. In the early 1960s, however, the area became increasingly trendy, "maybe because the poets knew the musicians who knew the painters who knew the dancers" (573). On the Lower East Side a new downtown Harlem Renaissance had arisen including the Umbra Workshop with its magazine, Freedomways magazine, La MaMa Experimental Theater or the Negro Ensemble Company. "If one wanted to be a poet in the early 60s, the Lower East Side was the place to be" (575).

According to Jones, Cooper Square is not a square, but a long triangle with its base the old brown Cooper Union building. When she first entered number 27, it had been vacant for years. Steep narrow stairs led up to the next two floors. In some of the rooms there were sections of the narrow pipe once used for gaslight, but none for cooking and heat. "In fact," Jones says about the dreary place, "it felt colder inside than out," as the (Hettie Jones 164). Nevertheless, Jones was immediately enthusiastic about living in a skylighted garret. "From Fourteenth Street we'd have to salvage gas heaters, toilet, stove - even the kitchen sink. Which like me remains on Cooper Square but linked to an earlier time and place. So that tonight, at the dishes, though twice her age I can also see that person I was at 
twenty-seven, bathing in her kitchen sink, with all of downtown at her back, and the morning sun ablaze in the poverty trees" (Hettie Jones 164).

Community gathering spots, including Beat bars like the Cedar and the Five Spot, which was also only a stone's throw away from Cooper Square, receive almost equal attention. All those places stick to her memory as reminders of happy days in the past. They play the role as symbols of memory: Places where famous and infamous beatniks gathered; where the literary and visual art scenes had their parties; where she and Roi lived happily together, raising their children; where she spent endless days typing Yugen. When Archie Shepp and his wife Garth moved into 27 Cooper Square, there were rehearsals and musical activity that involved Ornette Coleman, Don Cherry, Butch Morris and others. The sound of jazz was always in the air, as Jones remembers vividly: "the trumpeter Don Cherry would announce his arrival by playing a wooden flute, so clear it broke through the traffic noise. The acoustics of Cooper Square augmented every music: if it was warm weather when Archie's groups played, they'd open his studio windows and let the sound ricochet off the factories and repeat a millisecond later on the tenement wall on Fifth Street" (172; for more information on today's 27 Cooper Squar see <http://www.placematters.net/node/963>; Kaufmann<http://www.nytimes.com/2008/09/ 28/nyregion/thecity/28hote.html?_r=0>).

Before writing her memoir, Jones was hesitant to use the trope of "home" as the structural focus of her memoir, as she later recalls: "I thought, oh god, people are going to think this is corny! You know, women always talk about their homes" (qtd. in Grace, "Women" 124). However, she finally decided to use the "home"-concept for several reasons: "I wanted this to be a woman's book. I thought men would not focus on their homes. But here I mean 'home' not just in terms of where we lived, but 'home' as the art scene. So it seemed like the likely place to locate not only my life but the literary life. And also because of the business of race, where things come together in terms of race. So it seemed very logical" (124). Throughout the memoir, Jones depicts the places she calls home in vivid detail. She describes floor plans, the shape of rooms, furniture, the color of walls, or the nearness of her "own" space in connection to that of others. She carefully links one space that opens into another by the presence of her husband and children. Kitchen, sink, toilets, heaters, mattresses, desks, or chairs are carried from one place to the other when the family moved. Having no money, Jones is even happy about an old pair of sneakers she finds abandoned by the previous tenants of 27 Cooper Square. They fit perfectly and assume new life. Being aware that domesticity is often a cliché in women's autobiographies, she, nevertheless, found it a useful tool to depict the Village's and Lower East Side's 1960s art scene that represented "home" to her. In contrast to Kerouac and Cassady, who saw the US-American open road as their home, or Burroughs, who spent years in Mexico and South Ameri$\mathrm{ca}$, then lived in Rome, Tangier, Paris, and London before moving back to New York and later Lawrence, Kansas, Jones's narrative takes place in the domestic sphere. However, she depicts it in ironic terms and inverts the belief in home as something from which to escape. "Home" stands for the powerful rebuilding of her Beat past. By remembering past places, her memories are nurtured.

Seen in retrospect, both Joan Vollmer and Hettie Jones provided convenient homes not only for their husbands but also for Manhattan's developing Beat scene at large. Their achievement lies not only in being hostesses for musicians, writers, and intellectuals, but also in helping to build up a new identity for the emerging Beat counterculture. Vollmer's role during the early years of the Beats cannot be overstated, as it was Apartment 51 where Ginsberg first met Kerouac, and where Burroughs, Ginsberg, and Kerouac lived simultaneously. Similarly, Hettie Jones had the gift to link Beat writers, jazz musicians, Abstract Expressionist painters, or Black Mountain poets. Although Jones rebelled against the establishment, it is clearly shown that the domestic discourse is vital for her. "Home," meaning the artistic avant-garde, but also motherhood and children, plays a crucial role for Jones and many other female contemporaries. Paradoxically, female Beatdom derives from the domestic and does not resist it.

\section{Works Cited}

Baraka, Amiri. Home: Social Essays. New York: Morrow, 1966.

Charters, Ann. Kerouac. A Biography. New York: St. Martin's P, 1994.

Charters, Ann, and Samuel Charters. Brother Souls. John Clellon Holmes, Jack Kerouac, and the Beat Generation. Jackson: UP of Mississippi, 2010.

Gennari, John. "Baraka's Bohemian Blues." African American Review 37.2-3 (2003): 253-60.

Grace, Nancy. "Women of the Beat Generation: Conversations with Joyce Johnson and Hettie Jones." Artful Dodge 36-37 (1999): 106-33.

Grace, Nancy M., and Ronna C. Johnson. Breaking the Rule of Cool. Interviewing and Reading Women Beat Writers. Jackson: UP of Mississippi, 2004. 
Johnson, Joyce. Minor Characters. A Beat Memoir. New York: Penguin, 1999.

Johnson, Joyce. The Voice Is All. New York: Penguin, 2013.

Jones, Hettie. How I Became Hettie Jones. New York: Grove P, 1997.

Kaufmann, David. "At a Flashy New Hotel, a Pair of Eloises." nytimes (2008.09.26.):

<http://www.nytimes.com/2008/09/28/nyregion/thecity/28hote.html?_r=0>.

Maher Jr., Paul. Kerouac: The Definite Biography. Lanham: Taylor Trade Publishing, 2004.

Maurer, Daniel. "When Amiri Baraka Was LeRoi Jones, 'King of the Lower East Side'." bedfordandbowery.com

(2014.01.10.): <http://bedfordandbowery.com/2014/01/when-amiri-baraka-was-leroi-jones-king-of-the-lowereast-side/ $>$.

Miles, Barry. Call Me Burroughs: A Life. New York: Twelve, 2014.

Miles, Barry. Ginsberg: A Biography. New York: Simon and Schuster, 1989.

Morgan, Ted. Literary Outlaw: The Life and Times of William S. Burroughs. New York: Norton, 2012.

O'Neil, Paul. The Only Rebellion Around." Life (1959.11.30.): 115-30.

Schumacher, Michael. Dharma Lion: A Biography of Allen Ginsberg. New York: St. Martin's P, 1992.

Thomas, Lorenzo. "Alea's Children: The Avant-Garde on the Lower East Side, 1960-1970." African American Review 27.4 (1993): 573-78.

Watson, Steven. The Birth of the Beat Generation: Visionaries, Rebels, and Hipsters, 1944-1960. New York: Pantheon, 1998.

Watts, Jerry. Amiri Baraka: The Politics and Art of a Black Intellectual. New York: New York UP, 2001.

Author's profile: Heike Mlakar teaches English and Didactics at Hildesheim University (Germany). Her interests in research include EFL reading and writing and women writers of the Beat Generation. Mlakar's publications include "Playing the Recording Once or Twice: Effects on Listening Test Performances," International Journal of Listening (2016), and "Ausspracheschulungmithilfe von Raps," Englisch 5-10 (2018). Email: <mlakar@uni-hildesheim.de> 